Aline Batista de Paula

Construindo discursos que constroem sujeitos? Uma discussão sobre a contribuição da Lei 10.639/2003 e seu corolário para a afirmação de uma identidade racial positiva no Brasil

Dissertação de Mestrado

Dissertação apresentada ao Programa de Pós-graduação em Serviço Social da PUC-Rio como requisito parcial para obtenção do título de Mestre em Serviço Social.

Orientadora: Prof. ${ }^{\text {a }}$ Denise Pini Rosalem da Fonseca 
Aline Batista de Paula

Construindo discursos que constroem sujeitos? Uma discussão sobre a contribuição da Lei 10.639/2003 e seu corolário para a afirmação de uma identidade racial positiva no Brasil

Dissertação de Mestrado

Dissertação apresentada ao Programa de Pós-graduação em Serviço Social da PUC-Rio como requisito parcial para obtenção do título de Mestre em Serviço Social. Aprovada pela Banca Examinadora abaixo assinada:

Prof.- Denise Pini Rosalem da Fonseca

Orientadora

Departamento de Serviço Social - PUC-Rio

Prof. a Andréia Clapp Salvador Departamento de Serviço Social - PUC-Rio

Prof.- Maria Alice Rezende Gonçalves

Departamento de Educação - UERJ

Prof. a Monica Herz

Vice-decana de Pós-Graduação do Centro de Ciências Sociais-PUC-Rio 
Todos os direitos reservados. É proibida a reprodução total ou parcial do trabalho sem autorização da universidade, da autora e da orientadora.

\section{Aline Batista de Paula}

Graduou-se em Serviço Social pela Universidade do Estado do Rio de Janeiro - UERJ em 2006. Membro da Comissão de Gênero Etnia e Diversidade Sexual do Conselho Regional de Serviço Social - CRESS- RJ. Participou de vários Congressos relacionados à questão étnico-racial. Fez parte do SEMPRE NEGRO e do PROAFRO-UERJ.

Ficha Catalográfica

Paula, Aline Batista de

Construindo discursos que constroem sujeitos? Uma discussão sobre a contribuição da Lei 10.639/2003 e seu corolário para a afirmação de uma identidade racial positiva no Brasil / Aline Batista de Paula ; orientadora: Denise Pini Rosalem da Fonseca. - 2011.

$151 \mathrm{f}$; $30 \mathrm{~cm}$

Dissertação (mestrado)-Pontifícia Universidade Católica do Rio de Janeiro, Departamento de Serviço Social, 2011.

Inclui bibliografia.

1. Serviço social - Teses. 2. Lei 10.639/2003. 3. Identidade racial positiva. 4. A Cor da Cultura. 5. Promoção da igualdade racial. 6. Política pública de educação. I. Fonseca, Denise Pini Rosalem da. II. Pontifícia Universidade Católica do Rio de Janeiro. Departamento de Serviço Social. III. Título. 
Para minha mãe Dilléia, pelo apoio, paciência e amor de todos esses anos. 


\section{Agradecimentos}

Muitas pessoas importantes contribuíram para o término dessa etapa da minha vida. Sem elas esse trabalho seria impossível deixo aqui todo o meu carinho e gratidão.

Meus sinceros agradecimentos a minha família - avó, pai, tios, tias, primos e sobrinhos - pela compreensão da minha falta de tempo.

Agradeço os meus irmãos Marcos e Mayk por entenderem a minha ausência em quase todos os eventos familiares, pelo incentivo, pela compreensão de como esse projeto era importante para mim.

Tenho um agradecimento especial a minha tia Dilcéia e meu primo Douglas por serem meus modelos, eternos "padrão de qualidade" que me mostraram tudo o que eu poderia ser.

Agradeço aos mais fieis amigos Joilson e Ana Paula que me ajudaram de todas as formas possíveis com revisão de texto, buscando contatos, bibliografias e mais do que tudo com incentivo para me fazer continuar nos momentos mais difíceis e árduos. Amo Vocês.

Um carinho especial e respeito à minha mestra e amiga Magali Almeida pelo apoio e estímulo no decorrer dessa trajetória.

Agradeço a minha orientadora Denise Pinni pela paciência, suporte e troca desses anos.

Ao CNPq e à PUC-Rio, pelos auxílios concedidos, sem os quais este trabalho não poderia ter sido realizado.

Aos meus queridos colegas de turma um forte abraço pelo companheirismo, pela troca e prazer de sua companhia. Um abraço especial a Edith, Fernando, Bárbara, Denise e Sandra.

Agradeço aos professores do mestrado Sueli, Inês, Hilda, Andréa pelos ensinamentos e a funcionária Joana por toda ajuda.

E por fim um especial agradecimento a pessoa que mais me inspira minha mãe Dilléa, te amo de todo o meu coração. 


\section{Resumo}

Paula, Aline Batista de; Fonseca, Denise Pinni Rosalem. Construindo discursos que constroem sujeitos? Uma discussão sobre a contribuição da Lei 10.639/2003 e seu corolário para a afirmação de uma identidade racial positiva no Brasil. Rio de Janeiro, 2011. 151 p. Dissertação de Mestrado - Departamento de Serviço Social, Pontifícia Universidade Católica do Rio de Janeiro.

O objetivo do estudo dessa pesquisa visou primeiramente refletir sobre a Lei 10639/03, seu corolário e projetos de implementação, buscando identificar os alcances e limites que ela se expressa, e de que forma a resignificação da história e cultura negra contribuem para a construção de novos sujeitos coletivos. Para o desenvolvimento da pesquisa foi escolhido o projeto A Cor da Cultura, um dos projetos de implementação da lei, por intermédio da análise dos materiais que compõem seu kit e entrevistas com diversos atores sociais que o vivenciaram. A referida lei caracteriza uma política que busca combater toda e qualquer prática discriminatória e racista na comunidade escolar através de uma nova valorização do patrimônio cultural afrodescendente no Brasil. É notório que o espaço escolar reproduz uma série de conceitos, idéias e práticas que contribuem efetivamente com a construção do mito da inferioridade do negro. Não se pode deixar de levar em consideração o caráter ideológico da escola. Enquanto espaço privilegiado de socialização, a escola tanto pode contribuir para a transformação da sociedade quanto para manutenção das bases hierárquicas que possibilitam as desigualdades sociais. Das cinco entrevistas feitas, com capacitadores, professores, coordenadores, o que se pode identificar é que apesar de consideraram a importância da legislação enquanto instrumento de superação do racismo, também apontam a dificuldades encontradas no cotidiano da escola por falta de uma política efetiva.

\section{Palavras-chave}

Lei 10.639/2003; Identidade racial positiva; A Cor da Cultura; Promoção da igualdade racial; Política pública de educação. 


\section{Abstract}

Paula, Aline Batista de; Fonseca, Denise Pinni Rosalem (Advisor). Building discourses that construct subjects? A discussion on the contribution of Law 10.639/2003 and its corollary to the assertion of a positive racial identity in Brazil. Rio de Janeiro, 2011. 151p. MSc. DissertationDepartamento de Serviço Social, Pontifícia Universidade Católica do Rio de Janeiro.

This work deals with the 10.639/2003 Law, its corollary and implementation projects, with the goal of understanding its reaches and limitations. The purpose of this study is to understand how far the re-signification of the African and Afrodescendent Brazilian history can contribute to the construction of new collective subjects. To develop the fieldwork it was selected the project "The Color of Culture" (Fundação Roberto Marinho, Canal Futura), one of the most accepted and recognized application projects of the Law. The methodology included an analysis of the kit materials and the realization of five interviews, with several social agents involved with its implementation. That Law is a substantial part of a set of policies designed to oppose any form of racial discrimination through the educational system, by re-affirming the value of the Afro descendent cultural heritage in Brazil. It is well known that the school environment reproduces a series of concepts, ideas and social practices that effectively contribute to the construction of the black inferiority myth. In this context, it cannot be forgotten the ideological aspects of the educational system. For this reason, as a privileged socialization environment, the school holds a potential to transform society in terms of bridging social inequalities, as well as to maintain them. The research interviews were done with teachers, coordinators and project coaches. The findings point out to the fact that, although all the interviewed agreed on the importance of that Law as an instrument to surpass racism, they also recognize a lack of effectiveness of the policy in the day-to-day school life.

\section{Keywords}

Law 10.639/2003; Positive racial identity; The Color of Culture; Racial equality promotion; Public policy of education. 


\section{Sumário}

1. Introdução

2. A relação entre as Políticas Públicas de Promoção de Igualdade Racial e Serviço Social

2.1. O Pensamento Social Brasileiro e a formação de Políticas

Públicas de Promoção de Igualdade Social

2.2. O debate sobre raça, racismo e discriminação étnico-racial no Serviço Social e sua relação com o trabalho do assistente social nos dias de hoje

3. Novos rumos para a política pública de educação: democratização do acesso e permanência com ênfase na diversidade.

3.1 A Configuração das Educacionais no Brasil hoje

3.2 Políticas Públicas de Promoção da Igualdade Racial:

Educação para relações étnico-raciais.

3.2.1 - Lei 106399/03 - Novos sujeitos coletivos são possíveis?

4. Projeto "A cor da Cultura" - Novas formas de construção do conhecimento

4.1 Estrutura do Projeto

4.2 A cor da cultura - Novas formas de se pensar e ensinar Cultura Negra

$\begin{array}{ll}4.3 \text { Os materiais } & 70\end{array}$

4.4 Ouvindo os sujeitos $\quad 81$

4.4.1 Capacitador 83

4.4.2 Comitê Estadual Étnico-Racial 86

4.4.3 Coordenação municipal do Projeto A Cor da Cultura 90

4.4.4 Professores 98

5. Conclusão 107

6. Referências Bibliográficas 114

7. Anexos 118

Anexo I - Lei 10630/03 118

Anexo II - Plano Nacional de Implementação das

Diretrizes Curriculares nacionais da Educação das

Relações Étnico-Raciais e para o Ensino de História e

Cultura Afro-brasileira e Africana

Anexo III - Valores Civilizatórios Afro-brasileiros 148

Anexo IV - Lei 11645/2008 149

Anexo V - Roteiro de Entrevista do Professor $\quad 150$

Anexo VI - Roteiro de Entrevista Coordenador/Capacitador $\quad 151$ 


\section{Lista de siglas e abreviaturas}

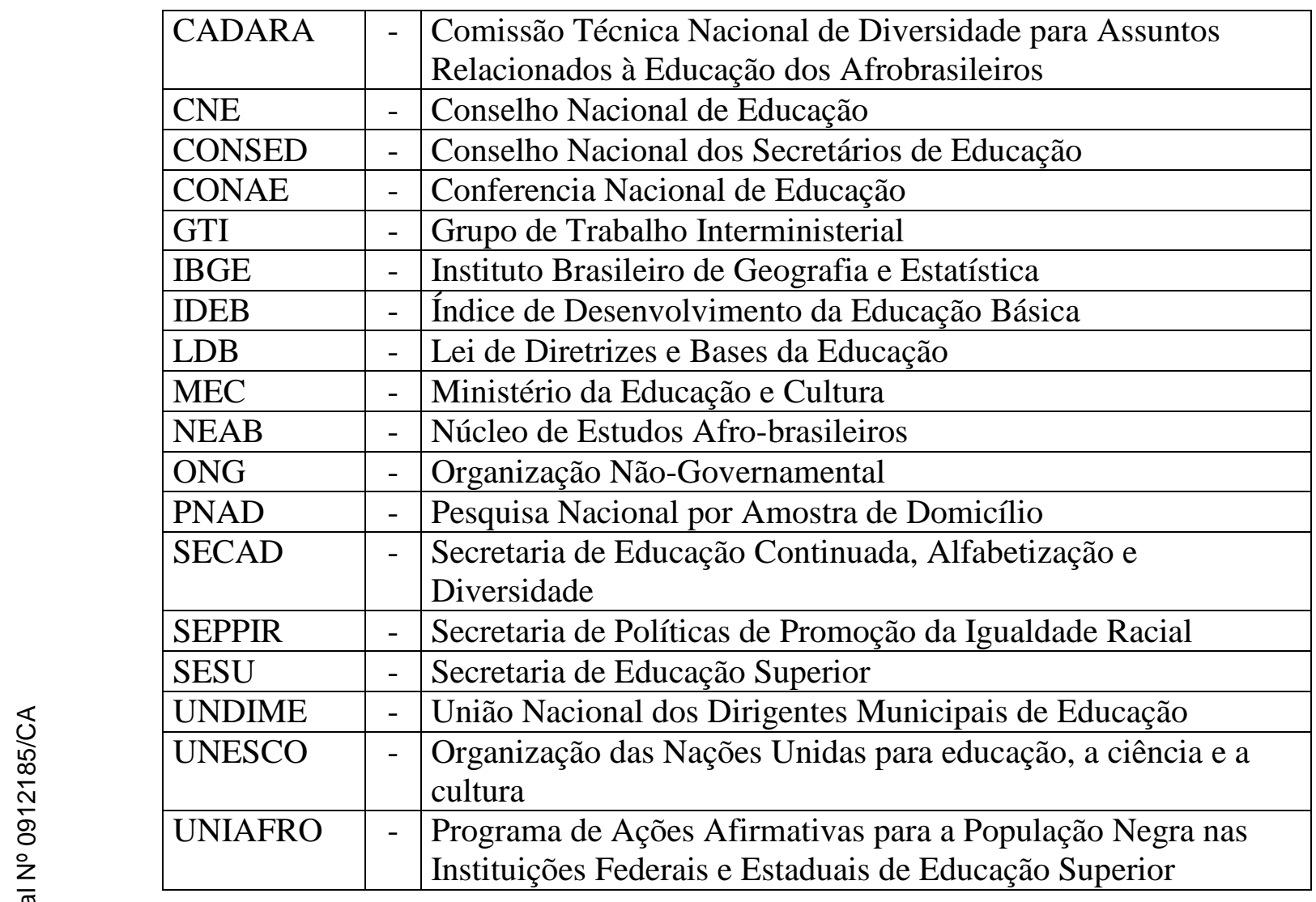

